\title{
HIPÓLITO E TESEU ENREDADOS NAS MALHAS DA DECISÃO INDISCUTÍVEL
}

\author{
CRistina de Souza Agostini*
}

Universidade São Judas Tadeu

\begin{abstract}
Resumo. O presente artigo propõe a discussão acerca das relações de poder estabelecidas pelos personagens Hipólito e Teseu, da tragédia Hipólito, de Eurípides. Nesse sentido, tendo como pano de fundo as considerações de Max Weber e Émile Benveniste para o uso do termo poder, pretendo demonstrar de que modo, no drama, a sanção da morte de Hipólito deve, necessariamente, ficar a cargo de Teseu, uma vez que este é o único personagem que, no contexto político da peça, detém legitimamente o poder sobre todos aqueles que estão sob seu domínio. Portanto, se, de um lado, no prólogo, Afrodite apresenta aos espectadores todo o desenvolvimento da tragédia, demonstrando sua atuação direta na ruína da família de Hipólito, de outro lado, Eurípides, de modo verossimilhante, vale-se da legitimidade do poder real de Teseu para selar com o veredito político humano a vontade da deusa Cípris.
\end{abstract}

Palavras-chave. Poder; Hipólito; Teseu; Max Weber; Émile Benveniste.

D.O.I. 10.11606/issn.2358-3150.v18i2p38-56

NÃo SE TRATA DE NENHUMA NOVIDADE QUE PALAVRAS DE NOSSA VIDA COTIdiana como democracia, igualdade e, mais recentemente, comunidade receberam inúmeras possibilidades semânticas que há, por exemplo, trezentos anos atrás não tinham o sentido que apresentam hoje. Aliás, a capacidade de absorver significados é algo completamente inerente à plasticidade de uma linguagem viva, ou seja, uma linguagem do aqui e agora na qual novos termos podem ser criados como resposta a um momento contextual em que os falantes, mesmo de forma não consciente, percebem que a arquitetônica de uma língua só é definitiva quando ela morre e, mesmo nesse caso, a autópsia promovida pelos filólogos-legistas tem se mostrado capaz de ressuscitar a inacabável construção das línguas não mais faladas.

Todavia, um dos efeitos colaterais mais audíveis decorrente da maleabilidade dos significados da linguagem foi a criação de "mantras linguísti-

\footnotetext{
Doutora em Filosofia pela Universidade de São Paulo (2013). A tradução das passagens em grego, bem como dos textos cuja bibliografia aponta para as edições em inglês e francês são de minha autoria.

“. Artigo recebido em 25.set.2015 e aceito para publicação em 14.dez.2015.
} 
cos", ou seja, termos que são repetidos à exaustão, nas mais diversas direções, como se fossem palavras destinadas a proporcionar algum tipo de relaxamento mental para o alcance de qualquer coisa que, decididamente, se torna inalcançável. Talvez, alguns dos termos que mais tenham sofrido ultimamente os efeitos de sua utilização enquanto mantra sejam democracia, liberdade, igualdade, família e poder, na medida em que se tornaram palavras de ordem sem qualquer espécie de reflexão sobre seus significados contextuais e históricos. Em suma, quando uma palavra se torna um mantra da sociedade dos falantes, o diálogo e o pluralismo significativo desaparecem para darem lugar ao êxtase ritualístico de (des-)concentração individual e estéril.

Desse modo, para que se consiga aqui fugir do lugar-comum contemporâneo das obscuras certezas mântricas terminológicas, e tenhamos delineado um terreno sólido e bem aplainado para a nossa presente discussão, a princípio, procurarei explicitar algumas considerações sobre o significado que a palavra poder adquirirá ao longo dessa exposição, uma vez que ela é a peça fundamental para a compreensão da perspectiva aqui adotada para o tratamento conferido às relações estabelecidas entre os personagens Hipólito e Teseu, da tragédia euripideana Hipólito. Assim, em um primeiro momento, é preciso conferir uma definição de poder, por mais calejados que, quanto a ele, estejam nossos ouvidos e discursos, pois é somente quando definimos os termos que estes podem se tornar pressupostos necessários para um posicionamento argumentativo.

O presente artigo foi concebido como fruto de uma reflexão sobre as atuações que os personagens Hipólito e Teseu, do Hipólito, de Eurípides, manifestam em relação às argumentações de outrem para a tomada de importantíssimas decisões. Na medida em que essa análise tem como foco, precisamente, as relações estabelecidas entre Hipólito e seu servo, e entre Teseu e seu filho bastardo Hipólito, comecei por interrogar de que maneira essas duas diferentes relações poderiam ser ambas caracterizadas como relações de poder. Assim, em uma primeira etapa, fez-se necessária a compreensão prévia do significado que poder atribui a essas relações para, então, a partir da configuração significativa desses dois momentos de confrontação (Hipólito e o servo, Teseu e Hipólito), possamos refletir acerca dos papéis que Eurípides confere ao fundador mítico da democracia ateniense e ao filho resultante de sua relação com a Amazona na configuração de uma arquitetura essencial para o desenvolvimento da ruína trágica do herói que, no contexto ateniense, é o mais poderoso no âmbito político: Teseu, o vencedor do labirinto e do minotauro.

Antes de começarmos a pensar sobre uma definição para o termo, a ser aplicada no caso concreto da peça, começarei distinguindo as duas 
acepções do uso conceitual de poder em nossa língua portuguesa. De fato, uma delas diz respeito à capacidade de conseguir algo, sem qualquer relação de conflito ou interesses como, por exemplo, quando digo "Hoje posso nadar cinco quilômetros", enquanto a outra expressa uma relação hierárquica e interesses em conflito. De fato, é justamente essa segunda acepção da palavra poder que nos interessa aqui.

Ora, para utilizar a terminologia aristotélica e por isso mesmo, valermo-nos do vocabulário grego a fim de tornar clara a diferente significação, em português, dos poderes, a clássica distinção de Aristóteles entre dynamis e ergon, ou seja, entre potência e ato, pode ser aqui evocada para a contraposição a kratos, que apresenta atrelados à sua significação a ideia de força, autoridade e hierarquia. Segundo o Estagirita, ${ }_{1}$ a potência (dynamis) compreende tanto uma virtualidade quanto uma capacidade determinada, ou seja, tanto o fato de Sócrates poder escrever tragédias, quanto o fato de Aristófanes poder compor comédias. No primeiro caso, existe a possibilidade de que Sócrates se torne tragediógrafo desde que aprenda a compor tragédias; no segundo caso, Aristófanes já apresenta os requisitos necessários para, quando quiser, colocar em prática sua habilidade. Ou seja, Sócrates é em potência um trágico, enquanto Aristófanes é em ato um autor de comédias, mas sua habilidade é também potencial quando ele está desempregado, no entanto, obviamente, em um sentido diferente do de Sócrates. Desse modo, tendo delimitado esse ponto, voltemo-nos para uma definição de poder no sentido político do termo, a fim de que possamos partir de uma ideia comum de como se estabelecem as relações de poder no Hipólito, de Eurípides.

Ora, não por acaso, cabe aqui citar um livro publicado em 1981, de Gérard Lebrun, intitulado O que é o poder?, de uma coleção chamada "Primeiros Passos", da editora Brasiliense. Nele, Lebrun articula importantes questões que nos auxiliam a pensar no delineamento político do poder. No entanto, embora o título do livro sugira a resolução de uma questão, na verdade, ele traz a elaboração da problemática a que todos aqueles que se propõem discutir cuidadosamente em que consistem as relações de poder estão implicados: com efeito, a filosofia nunca funciona como autoajuda, mas como uma pista do caminho a ser trilhado, e Lebrun nos ensina que, nesse caso, é preciso nos voltar para Max Weber.

Nesse sentido, o que proponho aqui é, a partir da junção de duas concepções de autores contemporâneos, estabelecer um definido campo comum para as relações de poder que se travam no Hipólito, de Eurípides e, mais especificamente, considerarmos de que forma se opera a confiança nas

${ }^{1}$ Sobretudo nos textos da Física e Metafísica.

Let. Cláss., São Paulo, v. 18, n. 2, p.38-56, 2014 
decisões tomadas por Hipólito e Teseu, decisões essas que excluem completamente a perspectiva e o argumento de outrem e que não requerem nada além da extrema confiança em si mesmo, deixando, portanto, de fora a possibilidade de falha ou engano no julgamento que ambos os personagens exercem acerca de suas ações.

Para Lebrun, a melhor definição já dada sobre poder é aquela de Max Weber. ${ }^{2}$ A díade poder-dominação (Macht und Herrschaft) é uma constante na obra weberiana, e apesar de suas reflexões adotarem uma perspectiva sociológica que não diz respeito especificamente à Antiguidade, acredito que tanto a elaboração de Weber quanto a análise de Émile Benveniste serão de imensa valia para meu propósito.

Segundo Weber, de um lado, "por poder, entendemos, aqui, genericamente, a probabilidade de uma pessoa ou várias impor, numa ação social, a vontade própria, mesmo contra a oposição de outros participantes desta"3 e, de outro, a dominação enquanto um caso especial do poder é uma

situação de fato, em que uma vontade manifesta ("mandado") do "dominador" ou dos "dominadores" quer influenciar as ações de outras pessoas (do "dominado" ou dos "dominadores"), e de fato as influenciam de tal modo que estas ações, num grau socialmente relevante, se realizam como se os dominados tivessem feito do próprio conteúdo do mandado a máxima de suas ações ("obediência"). ${ }^{4}$

Assim, o poder que nos interessa aqui consiste, precisamente, nessa definição que Weber confere à dominação enquanto ato concreto da manifestação do poder. No capítulo 7 do volume 2 do seu Vocabulário sobre as instituições indo-europeias, Benveniste escreve:

Krátos não significa nem "força física" (iskhús, sthénos), nem "força de alma" (alké), mas "superioridade, prevalência", seja no combate, seja na assembleia. ${ }^{5}$ [...] ele (o krátos) se desenvolve em uma série de termos com referência moral e política, enunciando o "poder" como faculdade individual (egkratés, akratés "quem é" ou "quem não é mestre de $\mathrm{si}^{\prime}$ ) ou o "poder" como "potência" territorial e política: kratein "ser mestre, ter a autoridade", com os inúmeros derivados e compostos em -krátes, -krátor, -krateia, etc., assim como os comparativos e superlativos kreisson, krátistos. É a "autoridade" política enquanto individual ou coletiva que faz a unidade desse desenvolvimento. ${ }^{6}$

Nesse sentido, a partir da junção e redução dessas duas análises, entendo poder como: a autoridade do agente para estabelecer uma vontade que será aquies-

\footnotetext{
${ }^{2}$ Cf. Lebrun 2003, 12.

${ }^{3}$ Weber 2009, 175.

${ }^{4}$ Weber 2009, 191.

${ }^{5}$ Benveniste 1969, 71.

${ }^{6}$ Benveniste 1969, 80.
}

Let. Cláss., São Paulo, v. 18, n. 2, p.38-56, 2014 
cida por determinado grupo de indivíduos. De onde se extrai o corolário: para que o agente seja investido de poder é absolutamente necessária a presença do outro, pois é impossivel deter o poder em mãos sem a contraparte obediente, ou seja, autoridade e vida solitária são incompatíveis, pois não há mando sem alguém que obedeça. Logo, tendo essa definição em mente, poderemos observar de que maneira ela opera em alguns momentos do Hipólito, de Eurípides.

O enredo da tragédia euripideana tem como motor as desgraças que se abatem sobre a vida do filho bastardo de Teseu, Hipólito. Este é um jovem cavaleiro, devoto incansável de Ártemis, que pretende em terra mimetizar o comportamento da deusa. Assim, ele rejeita a atividade sexual e o casamento, vivendo, espacialmente, em um território limítrofe em que pratica avidamente a caça e o culto à sua amada deidade.

$\mathrm{O}$ apego à virgindade e à efebia levam Hipólito a recusar a passagem para o outro lado da mureta em que se encontram Afrodite, o sexo, o casamento, as mulheres, a procriação e, no limite, a virilidade. Desse modo, sentindo-se ultrajada pelo rapaz, Afrodite - reiteradamente nominada como Cípris - vingar-se-á de sua maledicência e altivez, incutindo na esposa de Teseu, madrasta de Hipólito, Fedra, uma avassaladora paixão pelo enteado. Como o silêncio, definitivamente, não é um atributo feminino no ideário grego, Fedra não suporta a pressão exercida pela serva alcoviteira - que se coloca em posição de súplica - e acaba deixando escapar que o mal que a deixou acamada fora a inelutável paixão pelo bastardo. Embora tenha prometido que não contaria a ninguém sobre o vergonhoso pathos que dominara sua rainha, obviamente a serva de Fedra não cumpre com a promessa e revela a paixão proibida a Hipólito. Completamente indignado com a leviandade e imundícia da questão, o jovem rejeita qualquer possibilidade de incesto e, de quebra, desfere a famosa tirada misógina entre os versos 616-68:

Ó Zeus, por que trouxeste à luz do sol,

Este mal que engana os homens, as mulheres?

(...)

Odeio a perspicaz: em minha casa

Não haverá mulher pensando mais do que lhe convém.

De fato, a vileza, Cípris coloca muito mais

Nas perspicazes. A mulher limitada,

Os parcos conhecimentos subtraem-na de desejos impudicos.

Não era preciso haver servas junto às mulheres,

Mas a convivência das feras mudas e que mordem,

a fim de que não emitam voz alguma, nem recebam de volta som articulado.

É no interior que as vis decidem agir

De modo vil, vindo para o exterior por meio das servas.

Let. Cláss., São Paulo, v.18, n.2, p.38-56, 2014 
Ouvindo os gritos de Hipólito, Fedra se vê, literamente, com a corda no pescoço, e decide colocar em prática o plano que já vinha articulando ao longo da trama, plano esse que lhe possibilitaria fugir com eukleia da situação embaraçosa. Assim, a rainha resolve cometer o suicídio, mas, temendo que Hipólito entregasse a Teseu a paixão maculosa, o que destruiria sua pretensão de renome, ela deixa por escrito a acusação de que Hipólito houvera lhe estuprado, motivo esse mais que suficiente para explicar sua atitude desesperada em direção ao enforcamento.

Teseu que estivera ausente durante toda a ação, não mais que de repente, volta da consulta de um oráculo e recebe as novas de que Fedra está morta. $\mathrm{O}$ vencedor do minotauro é vencido pela crença nos grammata e no cadáver de sua esposa e, sem dar ouvidos aos argumentos do filho, ele bane o rapaz de Trezena e lhe dirige uma praga dada por Poseidon. Assim, Hipólito é estraçalhado por seus próprios cavalos. No final, Ártemis surge em cena e esclarece a verdade dos fatos a Teseu. $\mathrm{O}$ filho perdoa o pai e um culto etiológico em homenagem a Hipólito é prometido pela deusa.

De fato, Hipólito é um personagem limítrofe: ele vive nos limites da polis. É o único dentre os politai (monos politōn) ${ }^{7}$ a não cultuar Afrodite, cuja estátua se encontra ao lado daquela da deusa caçadora, revelando, desse modo, postura e comportamento bastante estranhos em relação aos demais cidadãos. Com efeito, o jovem cavaleiro é o único da região de Trezena a não cultuar uma deusa local, cuja devoção, veneração e rituais fazem parte de um costume compartilhado por todos. Ora, o culto à Afrodite não é estranho aos ritos comuns para que se possa, por exemplo, alegar que a esquiva à deusa seria justificada por sua própria natureza estrangeira. Nesse sentido, a recusa de Hipólito à Afrodite representa, em relação à deidade, uma hamartia no campo cultual e uma transgressão no âmbito cívico da polis.

Além disso, o cavaleiro exalta a todo momento sua sōphrosunē ligando-a a uma pretensa superioridade moral em relação aos outros homens. Desse modo, uma vez que Hipólito considera-se o superlativo de todas as qualidades humanas, conclui que pode cultuar a divindade que mais lhe agrade (e em seu caso, essa divindade é Ártemis), uma vez que é um homem, cuja posição privilegiada de contato com a deusa Amazona o isenta da comunidade de nomoi partilhada pelos demais cidadãos. Em outros termos, Hipólito se reconhece como alguém que está para além da humanidade, justamente porque suas aspirações, seus desejos e seu caráter não são compartilhados por outros homens, mas encontram satisfação na comunhão exclusiva com a divindade. Portanto, o jovem rompe com dois

${ }^{7}$ Eurípides, Hipólito, 12.

Let. Cláss., São Paulo, v. 18, n. 2, p.38-56, 2014 
princípios comumente partilhados pela tradição grega, a saber: a reverência a todos os deuses merecedores de honra e a compreensão da essencial inferioridade humana frente à inalcançável potência divina.

De um lado, sob o ponto de vista político, na medida em que Hipólito rejeita o culto a uma divindade local, bem como suas atribuições (o sexo e o casamento), recusa valores comuns cultivados por seus concidadãos, que permitem o reconhecimento do pertencimento à mesma comunidade, restando assim à margem da polis. De outro lado, sob o ponto de vista cultual, $\mathrm{o}$ desprezo e a difamação que o jovem atribui à Afrodite constituem uma falta grave contra uma divindade que deve ser venerada. Embora a desvinculação entre as esferas cultual e política na tradição grega clássica não seja algo facilmente determinável e nem é coerente imaginar uma separação radical entre os campos, parece razoável identificar no discurso da deusa a delimitação que esta faz em relação àquilo que pertence ao campo deídico e o que é da competência do âmbito público. Nesse sentido, não seria exagerado acreditarmos que a falta cometida por Hipólito concerne, antes de tudo, a uma questão política porque não diz respeito exclusivamente ao campo privado, mas se refere sobremaneira à esfera pública da comunidade de valores da polis. Nessa direção, a faísca detonadora da ira da deusa não é o fato de Hipólito cultuar Ártemis, pois como ela mesma diz no verso 20: “Disso não tenho ciúme - por que deveria?", contudo, a exclusividade cultual que o jovem mantém com apenas uma deusa, em uma sociedade essencialmente politeísta que, em termos práticos, significa para o rapaz a veneração à virgindade e ao isolamento e, portanto, a recusa em passar para um estágio natural do "ser homem" (cujo sexo e a procriação se encontram embutidos) é o que desperta a revolta de Afrodite. Além disso, Hipólito refere-se a ela como a pior (kakistēn) das divindades (v. 13) sem, aparentemente, ter consistente motivo para a difamação. Assim, a deusa é desprezada e difamada gratuitamente por um simples humano: um único cidadão. Logo, a vingança divina está provida de fortes e razoáveis motivações para que se exerça. Não se trata de mera inveja em relação à outra deusa, ou ainda de uma arbitrária antipatia por um mortal: o furor de Afrodite e sua consequente vingança são justos na medida em que respondem ao ataque deliberado de um cidadão que, embora conheça os valores e procedimentos partilhados em sua terra por seus concidadãos, vangloria-se em deitá-los fora sem que para isso apresente justificação legítima.

A escolha humana e suas consequências estão no cerne do Hipólito euripideano, mostrando de que modo os desejos individuais nem sempre se colocam em acordo com os costumes e com as práticas comuns. A antiga questão filosófica, formulada na seguinte pergunta "Como viver?" é trazida ao palco a partir do momento em que Afrodite começa a falar, e vemos que 
durante a ação dramática ela pode ser desmembrada em outra pergunta: "É permitido ao homem fazer o que ele quiser?" De fato, a conduta de Hipólito responde afirmativamente a tal questão: sim, os homens são livres para fazer o que quiserem, mas o corolário dessa pretensa liberdade é arcar com a responsabilidade e com as consequências inerentes à escolha de determinado modo de vida. Ao mesmo tempo em que temos a potência de fazer o que queremos, precisamente porque vivemos com outros, não é lícito fazer o que queremos sem mais e, então, as delimitações das vivências pública e privada traduzidas por regras de conduta dos agentes funcionam como expediente organizador dos diversos desejos para a convivência harmônica entre os diferentes integrantes de uma mesma comunidade. Ora, porque as questões pertencentes ao âmbito público dizem respeito à estabilidade, à ordem e à boa vivência de uma polis inteira, a não concordância de um cidadão particular em se adequar aos valores de sua comunidade e, consequentemente, adotar para si um modo de vida que passa ao longe dos costumes de seus concidadãos, adquire a qualidade transgressora inerente às ações que, de algum modo, podem provocar o desequilíbrio capaz de abater tanto uma casa quanto uma cidade inteira.

Assim, já no início do prólogo de Afrodite, marca-se de que maneira um mortal escolheu transgredir a conveniência local por vontade própria, sem a coerção de uma força externa. E é em decorrência dessa livre escolha que Hipólito arcará com as consequências que a deidade lhe impôs. A ancestralidade até certo ponto esclarece o comportamento do rapaz, mas como lembra Suzanne Saïd, a culpa ou a mácula de seus parentes sanguíneos não explicam o desastre que se abate sobre ele, ${ }^{8}$ ou seja, não esclarecem a vingança divina. Desse modo, o apelo à raça serve para compreendermos alguns traços que caracterizam Hipólito, tais como a ausência de desejo erótico, o amor pela equitação e a preferência cultual, mas, no entanto, não é a partir dela (da raça ancestral) que se evidenciam as razões pelas quais o cavaleiro é punido pela divindade.

Aliás, a escolha que Hipólito faz pela castidade não diz respeito apenas ao seu âmbito "privado", mas concerne ao quadro político da vivência em comunidade. De fato, a situação natural do homem antigo helênico era o casamento, responsável pela legitimidade da descendência (embora o próprio Hipólito não fosse legítimo) e também marca de virilidade. Portanto, na medida em que Hipólito rejeita o casamento, rejeita também a situação

8 "Mas é, sobretudo, o protesto de Hipólito no verso 1383 - 'Por que sobre aquele que não é de modo algum responsável (epaitios) desses males?' - que permite medir o que separa Ésquilo de Eurípides. Pois Eurípides emprega aqui a mesma palavra que Ésquilo utilizava para colocar em evidência a cooperação do indivíduo com o gênio da raça; mas ele o faz para rejeitar essa colaboração e para negar totalmente a culpabilidade de Hipólito" (Saïd 1978, 225). 
"natural" do homem cidadão que é a de constituir uma família e, com isso, propiciar à polis a continuação de sua linhagem e, consequentemente, a manutenção da cidade. Ademais, ao tentar igualar-se à deusa Ártemis, o jovem transgrede a conveniência de papéis estabelecidos, a saber, o de homem mortal inferior em tudo às divindades.

A fim de aconselhar o jovem cavaleiro acerca desse comportamento problemático, seu velho servo desenvolve um discurso marcado pela sensatez anciã. No entanto, o diálogo entre Hipólito e seu subalterno mostra a altivez do rapaz tanto quanto a intolerância que lhe doma. Nesse jogo cênico, percebemos a postura superior que Hipólito alimenta, traduzida na rejeição a tudo o que não seja considerado por ele mesmo como virtuoso, acrescido da intransigência em relação a ideias diferentes das suas. Em contraposição, seu servo demonstra uma atitude disposta a aconselhar sem impor e, levando em conta a devoção de Hipólito por Ártemis, ele tenta mostrar outra possibilidade cultual, sem que com isso descaracterize o pensar do jovem. De fato, nessa troca de palavras entre os dois, apresenta-se, formalmente, o topos da sensatez do mais velho oposta à impulsividade juvenil, mas, principalmente, é preciso notar de que maneira, desde o início da trama, se evidencia a inaptidão de Hipólito para se engajar com indivíduos inferiores ${ }^{9}$ : ele não consegue dialogar com o servo. Antes mesmo de o velho desenvolver o argumento que tem em mente, o cavaleiro o interrompe para lhe precaver a não dizer algo que seja contrário à sua convicção e, em seguida, continua seu trajeto, sem realmente ter conversado com o subalterno.

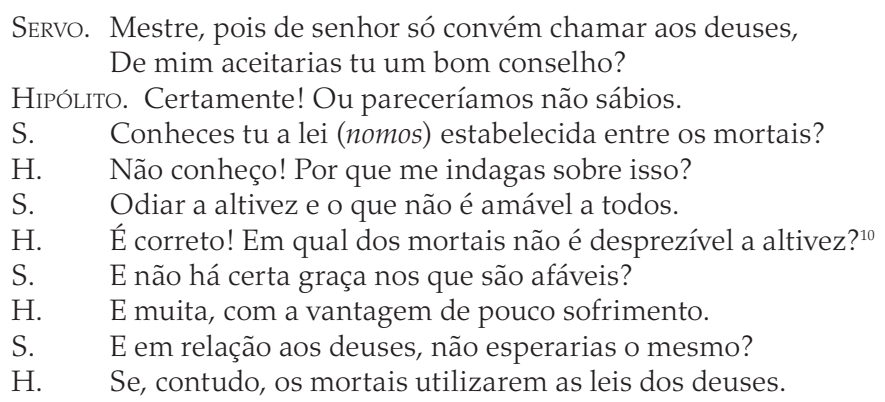

${ }^{9}$ Cf. Goff 2006, 90.

${ }^{10}$ Optei traduzir to semnon como altivez, uma vez que, em português, o termo apresenta tanto conotação reverencial, p.ex. "A divindade é altiva", quanto conotação de vanglória "Hipólito é muito altivo: acredita ser superior aos demais". Ora, em grego, a palavra pertence ao campo deídico, significando "reverendo, augusto, venerando", para os deuses. Assim, quando o servo aplica a mesma palavra de referência à divindade, para um mortal e, no caso, Hipólito, devemos entender que o cavaleiro confere a si próprio um tratamento que, de fato, diz respeito aos deuses. Barret, em seu comentário ao Hipólito nos é, sobremaneira, esclarecedor. Cf. Barret, Commentary, in Eurípides 2001, 177 n.93. 
S. Assim, por que tu não diriges a palavra a uma deusa altiva?

H. Qual? Tome cuidado para que tua boca não te destrua.

S. Esta que foi colocada às tuas portas: Cípris.

H. De longe a saúdo, uma vez que sou casto.

S. Mas é altiva, de renome entre os mortais.

H. Cada qual tem sua preferência, acerca de deuses e homens.

S. Seja feliz, tendo a sensatez de que é preciso.

H. Não me agradam os deuses honrados à noite.

S. Honras, ó filho, aos deuses são devidas. ${ }^{11}$

Hipólito não está aberto para um diálogo que problematize tanto seu desejo quanto seu comportamento. Ele é enfático em dizer que não lhe agradam as divindades "honradas à noite" (v. 106), sem apresentar um argumento que vá além do seu "agrado". Além disso, de fato, ele não aceita o bom conselho dado pelo homem mais experiente e, portanto, se mostra "não sábio".

Com efeito, a figura do servo mais velho é recorrente no teatro de Eurípides, muito mais que, por exemplo, em Sófocles. Ela demarca a fala sensata para a qual o herói deveria se voltar. No princípio do diálogo entre os dois, lemos: "Mestre (anax) - de senhor (despotas) só convém chamar aos deuses - / de mim aceitarias tu um bom conselho?".12 $\mathrm{O}$ jogo que se faz entre os termos anax e despotas é revelador da sabedoria e da humildade das quais o velho servo se utiliza para colocar ao jovem intolerante a possibilidade de culto de outra divindade: Afrodite.

Embora seja homem livre, quando se dirige à Ártemis, Hipólito coloca-se na posição de servo, utilizando o termo de tratamento despoina para com a deidade. Na medida em que Afrodite também é uma deusa, é tanto desejável quanto prudente que o jovem se comporte da mesma maneira com ela. Assim, por meio da própria invocação de Hipólito à Ártemis, o servo procura mostrar que a atitude do cavaleiro em relação à virgem marca o conhecimento de que unicamente aos deuses cabe a sujeição completa dos mortais e que isso deveria, então, ser estendido à Afrodite. De fato, o recurso que se faz à generalização do particular em direção ao universal, que na peça significa que a reverência prestada a uma divindade deve ser universalizada a todas, adquire como efeito dramático a caracterização de um herói que sabe agir segundo os nomoi, mas que por causa de sua arrogância e consideração elevada acerca de si mesmo, transgrede-os. Ora, o herói não apresenta uma falha moral: ele age de maneira justa em relação ao estabelecimento divino e humano, contudo, sua falta está no cumprimento

${ }^{11}$ Eurípides, Hipólito, 88-107.

${ }^{12}$ Eurípides, Hipólito, 88-89. 
de uma justiça particular, tornando-se assim um cidadão à margem de sua comunidade que partilha valores universais.

Hipólito desconsidera o conselho do servo que, hierarquicamente, encontra-se, de fato, em posição inferior à sua, mas como personagem mais velho oferece pontos de vista oriundos de uma vasta experiência de vida que não devem ser descartados. No entanto, quando olhamos de perto as relações que o filho de Teseu estabelece com outros humanos, percebemos que, apesar da sua contínua ostentação de superioridade, ele não está investido de poder, pois para que se trave tal relação, segundo a definição extraída de Weber e de Benveniste, a priori é necessário haver a presença de outrem. Ora, Hipólito exclui de seu modo de vida asceta as relações mortais que não sejam as que envolvam seus companheiros de caça. E mesmo com esses, embora assuma uma postura de liderança, não impõe seu modo de vida (já que é o único politēs a não cultuar Afrodite, e os outros caçadores não findarão como ele em uma eterna situação de efebia) e, portanto, percebemos que Hipólito não detém qualquer autoridade. Aliás, o único ser com quem o jovem efetivamente estabelece algum tipo do que podemos chamar relação é a deusa Ártemis com quem vive uma xuneinia. Contudo, embora a Amazona seja Senhora (despoina) e, portanto, hierarquicamente, ocupe posição superior à do rapaz, na prática, ou seja, em sua vida diária, Hipólito julga possuir quase o mesmo estatuto da deidade, não vendo diferença entre seu contexto situacional humano-mortal e o de Ártemis deusa-imortal. Logo, ele pode isentar-se das relações humanas porque é como se fosse um imortal que vive em terra. Todavia, penso que, de certo modo, a própria relação que Hipólito sustenta com a deusa e que serve de fundamento para a escolha pela vida casta e pela atividade da caça, não dá suporte para a marginalidade do herói traduzida na recusa ao mundo político-humano.

Nunca é demais lembrar que os nascimentos constituem um aspecto da polivalência do campo de atuação de Ártemis. Segundo Charles Segal, a rejeição ou ignorância de Hipólito sobre esse ponto é deliberada, ${ }_{13}^{13}$ constituindo um pseudo esquecimento. Ou seja, o filho de Teseu absorve apenas os domínios da deusa que lhe são convenientes, fazendo da vida a pura expressão de sua vontade: ele age como quer sem ceder às necessidades dos outros, sem ceder a convenções sociais. E mesmo no que diz respeito ao âmbito da devoção cultual, o rapaz incorpora somente as atribuições da divindade que corroboram para a escolha pela castidade, somente aquelas que fundamentam a permanência imutável. Desse modo, a virgindade, a caça, a equitação e a vivência nos limites selvagens da cidade são atribuições de

${ }^{13}$ Segal 1965, 160.

Let. Cláss., São Paulo, v. 18, n. 2, p.38-56, 2014 
Ártemis que o jovem experiencia em sua vida diária na medida em que elas não interferirão na vontade de perenidade. No entanto, o lado "parteiro" da deusa é deixado de lado por Hipólito. Ele ignora um aspecto fundamental de Ártemis que toda a tradição e todos os seus concidadãos conhecem, a fim de assegurar a coerência entre seu comportamento e a veneração pela Amazona. Com o propósito de fundamentar a conduta intocada, Hipólito solapa o nascimento de Apolo e, nesse sentido, torna-se difícil não o ver como um personagem "malandro" na medida em que a utilização que faz do deus deve adequar-se a seu próprio desejo de agir da maneira mais livre possível, sem qualquer cerceamento externo. Portanto, Hipólito não cultua todas as dimensões da deusa, porém, somente aquelas que lhe interessam, ou seja, aquelas que não contradizem seu modo de vida ascético. E, nesse sentido, não seria precipitado afirmar que a relação estabelecida entre o jovem e a divindade apresenta um aspecto instrumental, na medida em que ela serve de instrumento legitimador para um comportamento à margem.

No entanto, isso não significa dizer que a devoção de Hipólito não seja sincera. De fato, como vimos, ele coloca-se em posição subalterna apenas em relação à Ártemis, mas quando temos a presença de um outro que não a deusa, o próprio significado de relação é aniquilado, o que nos leva à conclusão de que a atividade cultual do cavaleiro se origina no poder que a irmã de Apolo exerce sobre o rapaz. Ora, é porque obedece a Ártemis que Hipólito, usando a terminologia de Max Weber, faz do conteúdo da vontade da deusa a máxima de suas ações. É porque a reconhece como poderosa que ele lhe é subordinado.

De todo modo, Hipólito tropeça na medida em que acredita que sua escolha está fora de questão e que, portanto, ninguém teria uma boa palavra ou uma boa sugestão para oferecer-lhe. Ele escorrega na super confiança de uma decisão que não tem outro dado que a crença em si mesmo, uma decisão que exclui a própria possibilidade de se pensar em outra perspectiva. Em suma, Hipólito confia demais na sua capacidade de discernimento que expurga todas as contribuições humanas.

Mas, se por um lado, podemos dizer que o excesso de certeza é o que leva à destruição do rapaz, por outro lado, foi precisamente por ter confiado em si mesmo que seu pai se tornou herói. Este preferiu enfrentar os perigos do caminho terrestre em direção à Atenas, pleno de delinquentes, a escutar os conselhos dos parentes mais velhos que o alertaram a seguir por mar. Aliás, Teseu nem mesmo cogitou a ideia de fazer um trajeto alternativo àquele que ele já houvera decidido. $\mathrm{E}$, do mesmo modo, aconteceu com o episódio do minotauro. O fundador mítico da democracia ateniense planejou ir à Creta entre os jovens que seriam sacrificados, sendo inflexível às súplicas de seu pai Egeu. E, assim, foi essa super confiança em si mesmo 
que fez com que Teseu se tornasse herói. Logo, vemos na intransigência de Hipólito a herança da physis do pai. Assim como Teseu, o jovem se nega a acolher conselhos que contrariem suas escolhas e decisões. Como seu pai, Hipólito acredita demais na infalibilidade de sua certeza.

Além de não desenvolver um diálogo com o servo, Hipólito também não o faz com a ama de Fedra. Após saber acerca da paixão que a rainha nutre por ele, o cavaleiro grita, recusa ser acalmado pela serva e, por fim, desfere a tirada misógina. Se de seu subalterno, Hipólito não aceitou considerar o conselho que expõe um modo de vida diferente daquele que leva, com a ama que, efetivamente, lhe diz algo vergonhoso, o rapaz não toma outra atitude que gritar e espernear, ou seja, ele não consegue dialogar e recusa o poder que necessariamente teria sobre uma "futura" esposa:

Ou alguém (tis) lhes ensine a ser prudentes (sōphronein didaxatō) Ou me permitam insultá-las para sempre. ${ }^{14}$

Assim, Hipólito rejeita não só o poder no âmbito da polis, na medida em que não almeja a sucessão do trono de Teseu, mas também o rejeita no âmbito do oikos. Ele mesmo não assumirá a responsabilidade masculina do controle da mulher que pode torná-la, entre outras coisas, prudente.

Após ouvir os insultos desferidos pelo enteado, Fedra enforca-se para, em seguida, Teseu retornar à Trezena, vindo da consulta ao oráculo. Diante do corpo da esposa e da tabuinha que incrimina o filho por estupro, o rei de Trezena sem qualquer dúvida conclui que Hipólito fora o responsável pela desgraça que se abatera sobre sua casa.

Na peça, Teseu é o personagem que legitimamente está investido de poder: ele é o rei de Trezena, filho de Egeu e tal como um Héracles, venceu inúmeros desafios que lhe conferiram tanto a autoridade no exemplo de conduta a ser seguida quanto a autoridade no campo político sobre os atenienses. Sua coragem e intrepidez são características marcantes da virilidade aspirada e admirada pelos cidadãos. Assim, é por meio de suas ações que Teseu conquista a reverência e obediência do povo, ou seja, por meio de seus exemplos ele conquista o poder. Em todos os desafios que enfrentou, ele saiu vitorioso e, de quebra, tornou a vida dos atenienses melhor. Suas decisões sempre se mostraram adequadas para cumprir as missões às quais ele se propôs com o objetivo de fazer de Atenas uma polis justa e gloriosa, e de seus habitantes, cidadãos livres e orgulhosos de sua terra.

${ }^{14}$ Eurípides, Hipólito, 667-8.

Let. Cláss., São Paulo, v. 18, n. 2, p.38-56, 2014 
Assim, tendo lido a acusação deixada por Fedra contra Hipólito, Teseu, antes mesmo de ver o filho, decide puni-lo com uma praga concedida por Poseidon. Com efeito, sem ainda ter conhecimento dos argumentos dos quais o jovem iria se valer, o rei decide que irá pedir ao pai divino a morte do bastardo. ${ }^{15}$

Na cena que se segue, Hipólito chega à casa do pai a fim de saber o motivo pelo qual este desesperadamente grita, e acaba compreendendo que é precisamente por sua causa. Ora, na confrontação de argumentos de Teseu e Hipólito acerca do estupro e suicídio de Fedra, a superioridade arrogada pelo rapaz em relação aos outros homens vira-se contra ele, adquirindo no contexto do ágon uma conotação viciosa e incriminadora. De fato, vemos que o cavaleiro é reconhecido e caracterizado pela posição orgulhosa, manifestada em discursos que exaltam suas virtudes e colocam-no em patamar acima do dos mortais. Com efeito, antes de ser lembrado por ações virtuosas, Teseu pensa o filho como o "homem extraordinário/o que convive com deuses ${ }^{\prime \prime 16} \mathrm{e}$, portanto, como presunçoso em decorrência de uma condição isenta de mácula. ${ }^{17} \mathrm{~A}$ fala de Teseu gira em torno da oposição entre a palavra e a ação do filho, pois enquanto Hipólito discursa exaustivamente acerca de sua condição privilegiada e excelente em relação a todos os outros homens, segundo a perspectiva de Teseu, suas ações não se coadunam com a vanglória de uma pretensa sōphrosunē que, diga-se de passagem é, ironicamente na peça, uma excelência mais feminina que masculina.

Com efeito, Hipólito age de maneira desviada daquilo que se espera de um verdadeiro homem, pois, iguala-se em atos a uma mulher e a identificação do rapaz ao feminino é mais um fator que ajuda a retirar dele qualquer traço de autoridade, uma vez que, por definição, as mulheres, sem capacidade de discernimento para a tomada de decisões, devem estar sujeitas aos homens que, legalmente, constituem-se como seus kurioi.

TESEU Mas o homem não tem desejos incontinentes

Como é natural brotar nas mulheres? Bem sei que os jovens

Nada estão mais seguros que as mulheres

Quando Cípris lhes toca o pensar na flor da idade,

Embora amparados por sua virilidade. ${ }^{18}$

Em comentário a essa passagem, Barret escreve :

\footnotetext{
${ }^{15}$ Eurípides, Hipólito, 887-90.

${ }^{16}$ Eurípides, Hipólito, 948-9.

${ }^{17}$ Eurípides, Hipólito, 950, 952.

${ }^{18}$ Eurípides, Hipólito, 966-70.
} 
Evidentemente, o ponto é que certa licença sexual é vista como normal para um homem, enquanto de uma mulher, espera-se que seja casta. Portanto, homens meramente por serem homens, são colocados fora da mesma conduta que traz para as mulheres má reputação. ${ }^{19}$

Assim, homens desfrutam de possibilidades sexuais que para as mulheres significariam depravação. Entretanto, apesar dessa licença para uma sexualidade mais frouxa, Hipólito sustenta a castidade e vangloria-se por ela, como se, efetivamente, pertencesse à raça de mulheres, e por essa associação Teseu pode acreditar que o rapaz possuído pela Cípria agiria, também, tal qual uma mulher, ou seja, de modo sexualmente descontrolado. Assim, a carta de Fedra e seu cadáver funcionam como prova suficiente para a culpa de Hipólito, cujos discursos de defesa passam a ser destituídos de crédito, antes mesmo de serem proferidos. Uma vez que as ações do jovem, anteriores aos fatos, demonstram a incoerência entre a superioridade arrogada por si e os valores de excelência compartilhados pela polis ou, em outras palavras, uma vez que aquilo que Hipólito não se cansa de anunciar que o faz superior aos demais é, precisamente, um comportamento que vai de encontro à excelência viril e à justiça da igualdade cultual, como acreditar na verdade de suas palavras de defesa? Logo, a condenação dada por Teseu ao filho, anterior às explicações deste, justifica-se na perspectiva da consideração de todo o comportamento do cavaleiro que sempre se vangloriou por aquilo que não é motivo de glória para nenhum homem. ${ }^{20}$

Com efeito, no início de sua defesa, Hipólito alerta para o fato de que não sabe falar para a multidão, um lugar-comum dos tribunais de Atenas a fim de assegurar a simpatia dos jurados, ${ }^{21}$ mas que nos lábios do cavaleiro, adquire efeito contrário, na medida em que ressalta seus ares de superioridade e soberba e, com sua característica ostentação de virtudes, o rapaz elabora a argumentação que o mostra como sōphron (v. 1007) e delineia a ambição de ser, nos jogos helênicos, o primeiro (prōtos); porém, na cidade, o segundo (deuteros) (vv. 1016-17). Destarte, utilizando os argumentos de que não possui nem desejo lúbrico, nem pretensão política, Hipólito defende-se da acusação de violação da madrasta.

Ainda que o governo cênico seja a monarquia de Teseu e, daí, então, a recusa política de Hipólito possa ser compreendida como recusa à pos-

${ }^{19}$ Barret, Commentary, in Eurípides 2001, 346.

${ }^{20}$ Vale aqui recordar que garantir a liberdade de fala para os filhos é também o que Fedra anseia com a morte e, embora Hipólito tenha tal liberdade para falar diante do pai, de antemão isso é irrelevante como instrumento de sua defesa. Com efeito, quando pensamos em parrēsia, não só devemos associá-la ao âmbito das decisões da assembleia, mas também ao campo jurídico dos tribunais, em que a fala é o elemento principal dos processos.

${ }^{21}$ Cf. Barret, Commentary, in Eurípides 2001, 348 n.986-7. 
sibilidade de ele mesmo tornar-se rei, na sucessão filial, o contentamento do jovem com o segundo lugar na cidade pode ser interpretado como o desejo por uma vida que privilegia o constante exercício da superioridade em questões particulares, ao invés de compartilhar com os outros cidadãos discursos medidos segundo o mesmo cânone. Além disso, ele não conta com a hipótese de que envelhecerá e de que, portanto, não poderá competir nos jogos atléticos eternamente, mas que deve abrir-se para outro tipo de competição, cujo discurso é aquilo que será colocado em combate.

Posteriormente à defesa do jovem, segue-se o diálogo entre pai e filho que reitera o posicionamento de Teseu em banir Hipólito, ainda que sem julgamento. Ora, de fato, a ausência de julgamento do rapaz relembra ao público a inflexibilidade mítica de Teseu e mostra como sua decisão se delineia a partir da certeza inabalável sobre o que é justo e sobre o que não o é, para determinar à população regida por suas leis o que deve ser feito, sem a possibilidade da contra argumentação. Aliás, a pena imposta a Hipólito por Teseu, de antemão, retira qualquer força jurídica que seu logos teria em um tribunal: utilizar palavras de defesa e não as utilizar passa a ser a mesma coisa quando o juiz, previamente, já decidiu pela condenação. No entanto, o rapaz segue lamentando a mudez da casa (v. 1075), sua única testemunha que poderia afirmar que está isento de culpa ${ }^{22}$ para, em seguida, receber mais uma acusação: a de que, sobretudo, venerava (sebein) a si próprio, deixando de lado a justiça devida ao pai (vv. 1080-1). O termo utilizado por Teseu, sebein, provém do âmbito cultual e denota a sacralidade com que Hipólito pensa a si mesmo, como mortal venerado, da mesma estirpe dos deuses. Por fim, a última fala do jovem, antes do início do terceiro estásimo, exalta Atenas com a lástima pela expulsão da gloriosa cidade. Portanto, ainda que Hipólito aja segundo ideias incompatíveis com aquelas da comunidade, sua admiração pelos valores da polis é evidente. O banimento da cidade gloriosa configura-se na última ruína do jovem: exilado não só da casa do pai, em Trezena, mas também da glória de Atenas que foi construída em grande medida por Teseu. Como salienta Barret, Hipólito "é um politēs de Trezena (12), mas é, primariamente, ateniense: sua morte diz respeito a Atenas e Trezena igualmente (...) ele é banido não apenas de Trezena (893), mas de Atenas". ${ }^{23}$

\footnotetext{
${ }^{22}$ Aqui, vemos a situação inversa que anteriormente fora invocada por Fedra no verso 418, a saber, a de que as mulheres adulteram sem o medo de que um dia os tetos possam falar e testemunhar suas faltas aos maridos. No caso de Hipólito, este conclama a casa como a testemunha que poderia provar que o adultério não fora consumado.

${ }^{23}$ Barret, Introduction, in Eurípides 2001, 34 n.1.
} 
Teseu é o único personagem humano que, na peça, emite uma ordem que é aquiescida por Hipólito, embora determine-o a fazer algo contrário ao que deseja. O único momento em que o cavaleiro faz alguma coisa que contradiga seu querer é decorrente da palavra real do pai. Ele é obrigado a deixar a casa de Teseu porque este elabora uma proposição que não é um conselho, mas um mandado, como diria Weber. Nesse sentido, somente o marido de Fedra, de fato e de direito, tem poder na esfera humana para levar a desgraça até as últimas consequências, e a vontade divina é consumada por meio do homem que encarna legitimamente o kratos. Se, por um lado, Fedra serviu de instrumento para a ruína de Hipólito, por outro, Teseu foi quem efetivamente o matou e, assim, ele é o responsável imediato pela morte do jovem, uma vez que é seu o veredito final que condena o devoto de Ártemis à miséria.

Com efeito, a vingança da Cípria depende completamente de mediações, uma vez que não é a própria deusa que, por exemplo, flagela ou causa diretamente a ruína de Hipólito. Fedra e Teseu são necessários para que o plano da divindade chegue a termo. Contudo, se de um lado, Fedra foi vitimada pelo dardo erótico e, consequentemente, a ação de ter escrito uma carta mentirosa possa, em certa medida, ser atribuída ao fato de estar sob o efeito de uma doença divina sem possibilidade de recusa -além da própria condição feminina da rainha, que já a coloca em enorme desvantagem no que se refere ao discernimento e sensatez - de outro lado, para Teseu, a mesma desculpa não pode ser aplicada: ele envia a praga mortal ao filho valendo-se exclusivamente de sua capacidade de compreensão dos acontecimentos. Diferentemente de Fedra, Teseu não foi tocado pela divindade, ou em outros termos, ele não está doente, porém, inteiramente apto para fazer o uso saudável e inalterado de suas faculdades racionais e humanas.

Nesse sentido, enquanto a princípio, Afrodite possa ser considerada a causadora do mal que abarca a família de Teseu, na verdade, sua vontade é concretizada no plano humano pelo mortal que, segundo Benveniste, "é a 'autoridade' política" e que integralmente se vale de suas capacidades humanas, sem qualquer interferência deídica para decidir pela destruição de Hipólito: o que se iniciou com a divindade do céu, termina com o homem mais poderoso da terra de Trezena.

Aliás, a certeza de Teseu sobre a culpa do filho a partir da inércia das provas que Fedra deixara é especialmente interessante. Em sua defesa, Hipólito chama a atenção para a precipitação da decisão do pai que não esperou o tempo revelar (mēnutēn khronon, 1051) os verdadeiros acontecimentos, nem requereu juramento (horkon, 1055), prova (pistin, 1055) ou oráculo divino (manteōn phèmas, 1056) antes de lhe exilar e invocar a praga de Poseidon. Ademais, é ironicamente trágico pensar que, momentos antes, 
Teseu estava em contato com oráculos ${ }^{24}$ : ele chega à Trezena após ter feito uma consulta oracular; mas no que concerne aos acontecimentos ocorridos dentro de sua casa, ele não precisa de nada além da sua indiscutível capacidade de elucidação dos fatos. E embora entre os versos 1320-24, Ártemis lhe recrimine como kakos por não ter exigido prova (pistin), adivinho (manteōn) ou ter esperado bastante tempo (khronoi makrōi), quando nos voltamos para os desafios míticos e heroicos de Teseu, nos apercebemos de que ele também não houvera consultado oráculos. Em Eurípides, o personagem Teseu segue o padrão (que os atenienses já conhecem) de confiança em sua própria perspicácia na consideração dos fatos, comportamento esse que, no final das contas, conferiu-lhe reputação e poder. Enquanto no mito, é acreditando no seu raciocínio que Teseu vence todos os malfeitores, é reconhecido por Egeu e mata o minotauro; na peça é essa mesma crença no próprio poder de decifração, a qual dispensa algo além de si mesmo na tomada de decisões, que arruína a vida do fundador mítico da democracia ateniense. Desse modo, se por um lado, no mito sobre suas aventuras, aprendemos que o herói obteve sucesso exclusivamente graças a desconsideração de opiniões alheias, por outro lado, na tragédia, observamos que mesmo Teseu está sujeito ao engano, quando seguro de sua incorruptibilidade analítica, não dá ouvidos a outra voz diferente daquela que foi emudecida pela fixação em uma tabuinha.

\section{REFERÊNCIAS}

Benveniste, E. 1969. Le vocabulaire des institutions indo-européennes. 2. Pouvoir, droit, religion. Les éditions de minuit.

Euripides. 2001. Hippolytos. Edited with Introduction and Commentary by W.S. Barret. Oxford: Clarendon Press.

Eurípides. 2007. Hipólito e Fedra. Três tragédias. Estudo, tradução e notas de Joaquim Brasil Fontes. São Paulo: Iluminuras.

Goff, B. 2006. The noose of words. Readings of desire, violence \& language in Euripides' Hippolytos. Cambridge University Press.

Karsai, G. 1990-1991. "Parole et silence des devins dans le théâtre antique: la divination et la faute dans l'Hippolyte d'Euripide." Cahiers du GITA 6:161-71. Montpellier: Université Paul Valéry.

Lebrun, G. 2003. O que é poder? Tradução de Renato Janine Ribeiro e Silvia Lara. São Paulo: Editora Brasiliense.

Saïd, S. 1978. La faute tragique. Paris: Maspero.

${ }^{24}$ Cf. Karsai 1990-1991, 165. 
Segal, C. 1965. "The tragedy of the Hippolytus: the waters of ocean and the untouched meadow." HSCP 70:117-69.

Weber, M. 2009. Economia e sociedade: fundamentos da sociologia compreensiva. Volume 2. Tradução de Regis Barbosa e Karen Elsabe Barbosa, revisão técnica de Gabriel Cohn. Brasília: Editora da Universidade de Brasília.

\section{$*$}

Title. Hippolytus and Theseus and the indisputable decision

Abstract. This paper discusses the relations of power established by the characters Hippolytus and Theseus in Euripides's Hippolytus. Based on Max Weber and Émile Benveniste in what concerns the use of the term power, I shall demonstrate the way in which Hippolytus death sanction must carried out by Theseus as he is the only character - in the political context of the play - that legally retains the power over all those under his authority. Hence, if on the one hand, Aphrodite, in the prologue, presents the spectators the whole development of the tragedy, showing her direct intervention in the ruin of Hippolytus' family, on the other hand Euripides uses in a likely way the legitimacy of Theseus's royal power to enforce the will of the Cyprian goddess through a human and political verdict.

Keywords. Power; Hippolytus; Theseus; Max Weber; Émile Benveniste. 